\title{
Pos Saling Toga: Pos Sadar Lingkungan Tanaman Obat Keluarga
}

\author{
Pinasti Utami ${ }^{1 *}$, Ingenida Hadning1, M. T. Ghozali'1, Muhammad Fariez Kurniawan ${ }^{1,}$, \\ Sabtanti Harimurti' ${ }^{1}$, Bangunawati Rahajeng', Azizah Khoiriyati², Devi Puspitasari ${ }^{1}$
}

\author{
1*. Program Studi Farmasi, Fakultas Kedokteran dan Ilmu Kesehatan, Universitas Muhammadiyah Yogyakarta, Jl Brawijaya, Tamantirto, \\ Kasian, Bantul, Yogyakarta,55183, +6281904083266 \\ $2^{*}$. Program Studi Keperawatan, Fakultas Kedokteran dan Ilmu Kesehatan, Universitas Muhammadiyah Yogyakarta, Jl Brawijaya, Tamantirto, \\ Kasian, Bantul, Yogyakarta \\ Email: Email: pinasti.utami@umy.ac.id \\ DOI: $10.18196 / p p m \cdot 34.279$
}

\begin{abstract}
Abstrak
Gencarnya gaya hidup back to nature berdampak pada perilaku masyarakat dalam konsumsi tanaman obat baik yang masih alam maupun yang sudah dalam bentuk sediaan. Minimnya pengetahuan mengakibatkan penggunaan Tanaman Obat Kelvarga (TOGA) yang kurang bijak, selain itu minimnya lahan terbatas juga membuat sulit untuk membudidayakan. Untuk itu pengabdi tergerak untuk meluruskan dari penyimpangan penggunaan TOGA dan mengajarkan tanaman tumbuh dalam pot (Tambulampot). Mitra yang digaet adalah Lembaga Lingkungan Hidup dan Penanggulangan Bencana Pimpinan Wilayah Aisyiyah Daerah Istimewa Yogyakarta (LLHPB PWA DIY) yang memiliki fokus terhadap permasalahan lingkungan, dengan menggerakkan potensi wanita. LLHPB memiliki 5 kader Aisyiyah di tiap kabupaten sehingga harapannya bisa ditularkan di tingkat ranting. Kegiatan ini dilaksanakan pada tanggal 15 Maret 2020 di Kampus Terpadu Universitas Muhammadiyah Yogyakarta dihadiri oleh 35 peserta dari LLHPB. Pada kegiatan ini juga menyosialisasikan Modul SALING TOGA di mana tiap peserta diukur dari pretes dan postes untuk evaluasi tingkat pemahaman. Pada kesempatan ini tiap daerah/POS diberikan paket TOGA sesuai penyakit yang marak dikalangan masyarakat diantaranya gangguan pada Nafas, Hormon, Cerna, Jantung dan Syaraf. Hasil program ini menunjukan adanya peningkatan pemahaman sebesar 13,7\% tentang TOGA. Hal ini menunjukkan bahwa sosialisasi bermanfaat bagi peningkatan pengetahuan bagi para kader dan harapannnya bisa secara rutin.
\end{abstract}

Kata Kunci: LLHPB, Pengurus Daerah Aisyiyah, Tambulapot, SALING TOGA

\section{Pendahuluan}

Peran penting perempuan dalam memberikan kontribusi bagi kemajuan suatu bangsa sangatlah strategis. Hal tersebut karena perempuan memiliki kekuatan hati dan berpegang te guh terhadap prinsip. Aisyiyah sebagai salah satu organisasi persyarikatan Muhammadiyah, sejak berdiri hingga saat ini berkomitmen untuk meningkatkan derajat dan martabat kaum perempuan Indonesia. Fokus pada organisasi ini adalah pada program dan gerakan melalui pendidikan, kesehatan dan pemberdayaan masyarakat. Di dalam kepengurusan Aisyiyah memiliki jenjang dari Pimpinan Pusat Aisyiyah turun ke wilayah menuju daerah dan ujung tombaknya melalui ranting (www.yogyakarta aisyiyah.or.id, 2020).

Pengabdian kali ini berfokus pada pengaderan level Pengurus Daerah yang dirangkul Pimpinan Wilayah Aisyiyah melalui Lembaga Bidang Lingkungan Hidup dan Penanggulangan Bencana (LLHPB) yang bekerjasama Prodi Farmasi FKIK UMY. Daerah Istimewa Yogyakarta memiliki 4 Kabupaten dan 1 Kotamadya. LLHPB memiliki komitmen yang kuat dalam menyelesaikan permasalahan di level daerah sehingga setiap satu bulan di minggu kedua selalu terdapat koordinasi untuk menyelesaikan permasalahan-permasalahan tersebut. Harapan yang dibentuk kader-kader pada level PDA agar kader tersebut nantinya akan menularkan ke ranting sehingga kebermanfaatannya akan semakin banyak dinikmati.

Topik POS Sadar Lingkungan Tanaman Obat Keluarga (POS SALING TOGA) yang diangkat pada pengabdian ini, merupakan topik usulan yang setelah dilakukan kajian bersama mengingat makin beragam penyakit yang menyebabkan masyarakat kembali mengangkat jarkon 
back to nature. Menurut penelitian Hikmat (2011) menunjukkan bahwa masih rendahnya pengetahuan dan perilaku masyarakat dalam pemanfaatan TOGA bagi kesehatan dan ekonomi keluarga. Hal ini disebabkan karena rendahnya pengetahuan masyarakat tentang jenis tanaman dan manfaatnya bagi kesehatan. Untuk itu diperlukan pengetahuan yang bijak untuk mewadahi usulan tersebut, mengingat maraknya obat-obat yang bisa dijual secara bebas melalui online baik dalam bentuk sediaan maupun tanaman asli, serta pada masa pandemi ini TOGA menjadi marak dengan klaim dapat digunakan untuk obat Corona Virus Disease 2019 (COVID 19) sehingga perlu pemahaman perbedaan dari spesifik dan manfaatnya. TOGA merupakan jenis tanaman yang dikoordinir budidayanya, biasanya ditanam di sekitar pekarangan rumah sehingga bisa dimanfaatkan untuk memenuhi kebutuhan obat-obatan keluarga dengan cara pengolahan atau peracikan yang dapat dilakukan oleh semua orang secara sederhana (Gendrowati 2014). Kendala yang dihadapi selain minim pengetahuan tentang TOGA adalah lahan yang digunakan untuk budidaya semakin sempit, untuk itu perlu diberikan solusi yaitu dengan menggunakan tambulampot. Tambulampot adalah tanaman tumbuh dalam pot yang merupakan salah satu solusi bagi para pecinta tanaman di perkotaan yang notabene mempunyai lahan yang terbatas (arifah, 2017). Untuk itu tujuan dari kegiatan ini adalah membentuk Kader/ POS SALING TOGA di tiap daerah dengan menggandeng LLHPB PWA Yogyakarta sebagai mitranya.

\section{Metode Pelaksanaan}

Metode Pelaksanaan pada kegiatan ini dilakukan melalui tiga program kegiatan yang meliputi:

1. Rekruitmen Kader Aisyiah POS SALING TOGA, dengan cara memilih perwakilan Pimpinan Daerah Aisyiah DIY minimal 5 orang tiap daerah.

2. Pelatihan mengenai tanaman obat dengan mendatangkan pakar dengan latar belakang Farmasi bidang bahan alam dan sosialisasi Modul SALING TOGA. Untuk mengukur kemampuan para kader maka dilakukan pretes dan postes terkait TOGA.

3. Workshop budidaya TOGA dalam tambulapot.

Pada kegiatan ini akan dipandu oleh pakar pertanian bidang budidaya tambulampot. Para Kader akan dilatih bagaimana cara menanam dengan baik sesuai dengan paket tanaman yang sudah dibagi.

Dari masing-masing daerah disosialisasikan dengan menggunakan Modul SALING TOGA di mana modul ini memuat 5 sistem organ yang sering bermasalah dilengkapi 3 tanaman obat yang bisa mengatasi gangguan pada nafas, hormon, pencernaan, jantung dan syaraf. Adapun tiap tanaman obat berisi tentang nama latin, kandungan, manfaat, cara pakai, efek samping dan larangan. Gambar 1 tentang skema alur pengabdian dan Gambar 2 pembagian tanaman berdasarkan daerah yang disesuaikan dengan paketnya. 


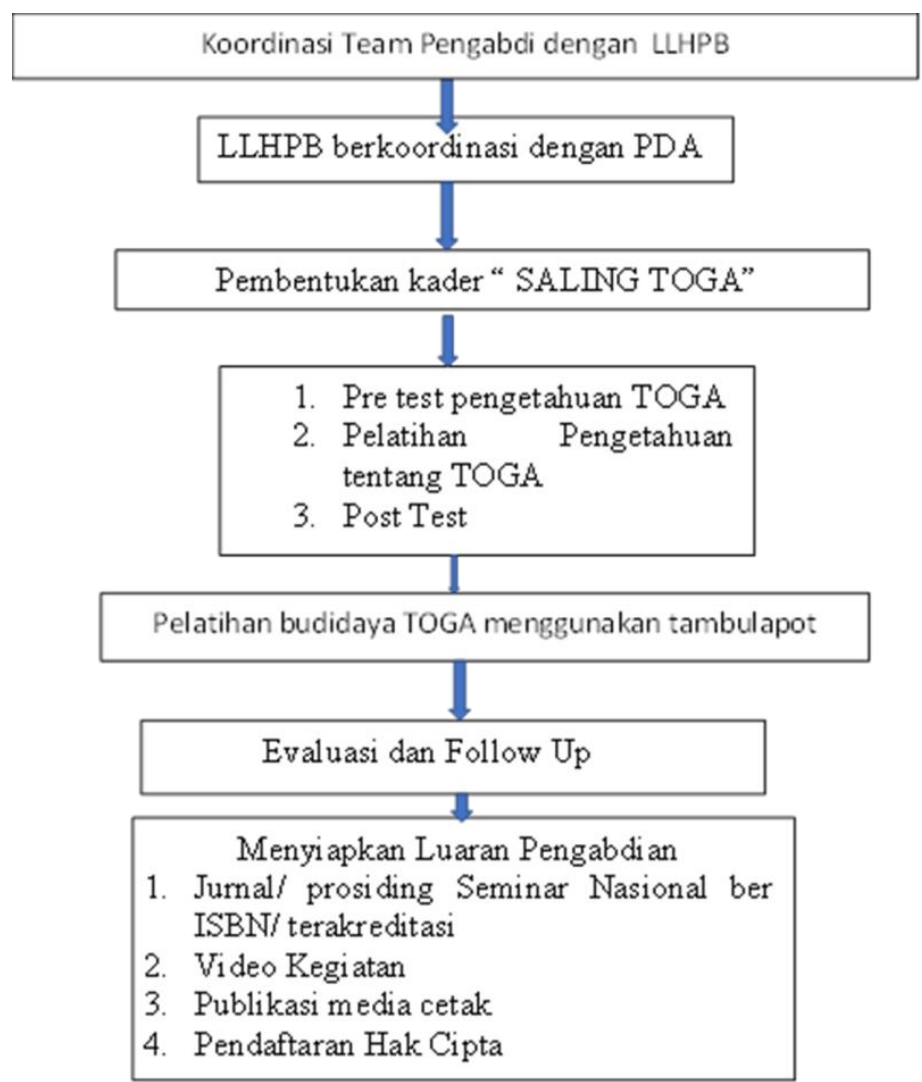

Gambar 1. Skema Kegiatan Pengabdian



Analisis data yang digunakan untuk mengukur tingkat pemahaman para kader melalui pretes dan postes akan dihitung menggunakan microsoft exel yang kemudian diambil dari rata-rata hasil nilai tersebut kemudian diukur tingkat peningkatannya.

\section{Hasil dan Pembahasan}

Gencarnya gaya hidup back to nature berdampak pada perilaku masyarakat dalam konsumsi tanaman obat baik yang masih alam maupun yang sudah dalam bentuk sediaan. Minimnya pengetahuan pada hal tersebut mengakibatkan pengunaan Tanaman Obat (TOGA) yang kurang bijak, untuk itu pengabdi tergerak untuk melurusan dari penyimpangan penggunaan 
TOGA. Mitra yang digaet adalah Lembaga Lingkungan Hidup dan Penanggulangan Bencana Pimpinan Wilayah Aisyiyah Daerah Istimewa Yogyakarta (LLHPB PWA DIY) yang memiliki fokus terhadap permasalahan lingkungan dan kebencanaan, dengan menggerakkan potensi wanita. Pembentukan kader Aisyiah dalam rangka upaya peningkatan "SALING TOGA" Sadar Lingkungan Tanaman Obat Keluarga. Selain itu pada pengabdian ini juga mengangkat pelatihan Tanaman tumbuh dalam pot (tambulapot) yang dilaksanakan pada tanggal 15 Maret 2020 di Kampus Terpadu Universitas Muhammadiyah Yogyakarta dihadiri oleh 25 peserta dari Pengurus Cabang LLHPB, 10 peserta Pengurus Daerah LLHPB dan 10 Panitia dari Pihak Prodi Farmasi FKIK UMY.

Pada kegiatan ini mengundang pakar dari pertanian dalam upaya pemberdayaan budidaya TOGA pada lahan yang terbatas oleh Devi Puspitasari, S.P dan pakar pengembangan obat dan bahan alam oleh apt. Muhammad Fariez Kurniawan, M.Farm sedangkan penggerak dari Prodi Farmasi FKIK UMY dikerjakan oleh para dosen apt. Pinasti Utami, M.Sc, apt. Ingenida Hadning, M.Sc, apt. Dr.Bangunawati Rahajeng, M.Sc, apt. Sabtanti Harimurti, Ph.D, apt. MT Ghozali, M.Sc, dan Azizah Khoiriyati, S.Kep., Ns., M.Kep yang melaksanakan kegiatan pengabdian masyarakat berjudul "SALING TOGA" Sadar Lingkungan Tanaman Obat Keluarga. Pemilihan mitra kali ini adalah LLHPB PWA Yogyakarta karena mitra memiliki jaringan yang luas dalam mencari kader kader SALING TOGA, sehingga kegiatan ini bisa tepat sasaran dan memberikan pengarahan agar dapat ditularkan ke sekup yang lebih luas yaitu ranting, karena ranting adalah ujung tombak yang menyentuh langsung dengan masyarakat. Selain LLHPB, mitra internal adalah Program Studi Farmasi, yang aktif dalam melakukan kegiatan pengabdian masyarakat, terutama dalam bidang kesehatan.

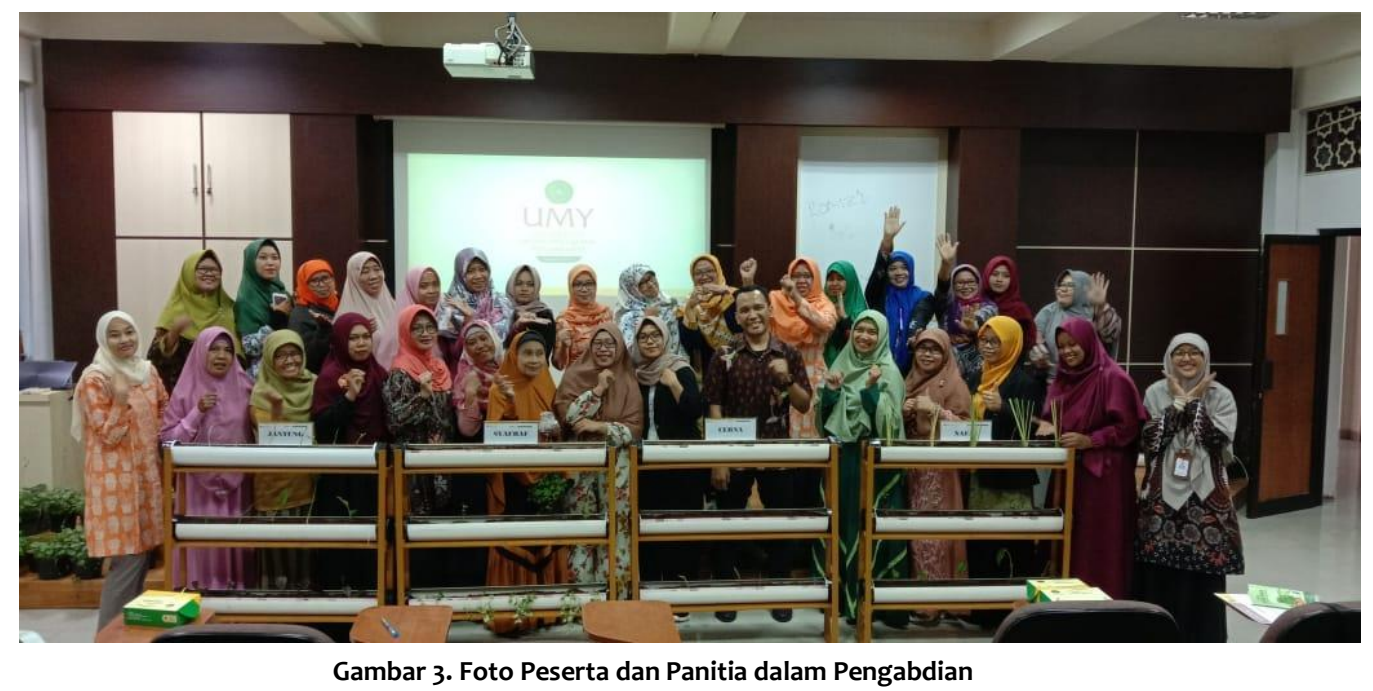

Kegiatan ini, dibuka langsung oleh Ibu Hj Siti Zulaihah Ketua Pimpinan Wilayah Aisyiyah Yogyakarta dengan menggerakan dan membentuk kader SALING TOGA, dengan 5 orang di tiap Daerah atau Pimpinan Wilayah Aisyiyah (Sleman, Bantul, Kulonprogo, Kota Yogyakarta dan Gunung Kidul). 


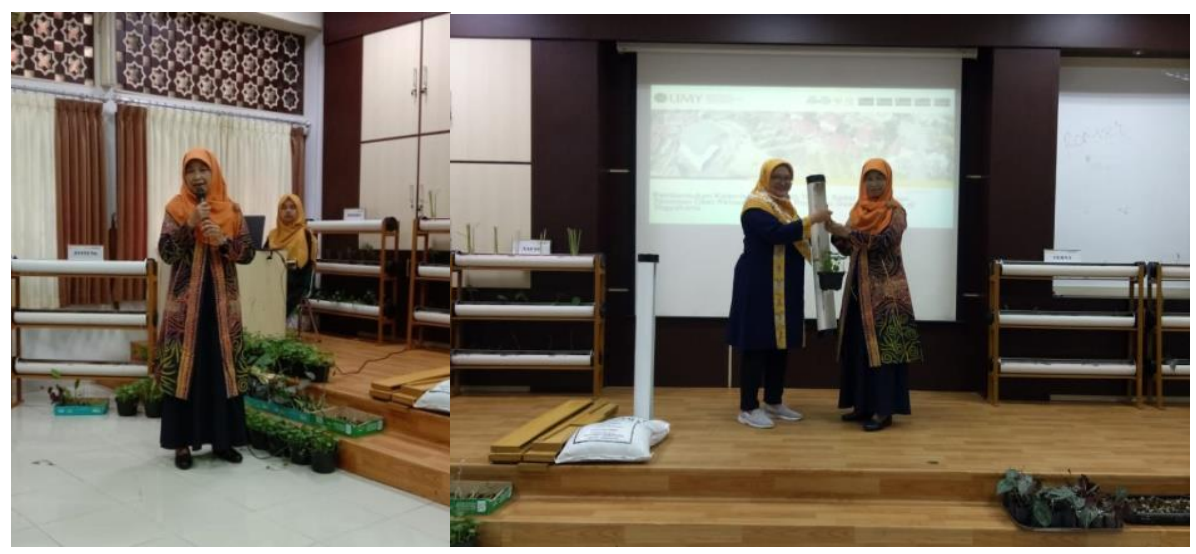

Gambar 4. Pembukaan dan Serah terima barang

Kegiatan ini diawali dengan koordinasi dengan pihak eksternal LLHPB PWA DIY untuk merumuskan teknis kegiatan. Setelah itu berbagi tugas untuk pihak mitra menyiapkan kader kader Aisyiyah dari 5 kabupaten/kotamadya DIY sedangkan pihak pengabdi menyipakan materi penyuluhan, buku modul dan perangkat/ paket yang akan digunakan untuk pelatihan berupa 3 tanaman tiap gangguan organ dan media yang digunakan untuk menanam berupa pot, tanah dan pupuk. Berikut tabel tanaman di tiap daerah:

Tabel 1. Tanaman dan pembagian wilayah

\begin{tabular}{llll}
\hline No & Wilayah & Tanaman & Fungsi \\
\hline 1 & Sleman & kunyit, jahe, kencur & Gangguan Pencernaan \\
2 & Bantul & mint, serai, sirih. & Gangguan Pernafasan \\
3 & Kulonprogo & Pegagan, daun ungu, jahe & Gangguan Saraf \\
4 & Kota Yogyakarta & kunyit, sirih merah, temu lawak & Gangguan Jantung \\
5 & Gunung Kidul & pegagan, stevia dan kemangi & Gangguan Endokrin \\
\hline
\end{tabular}

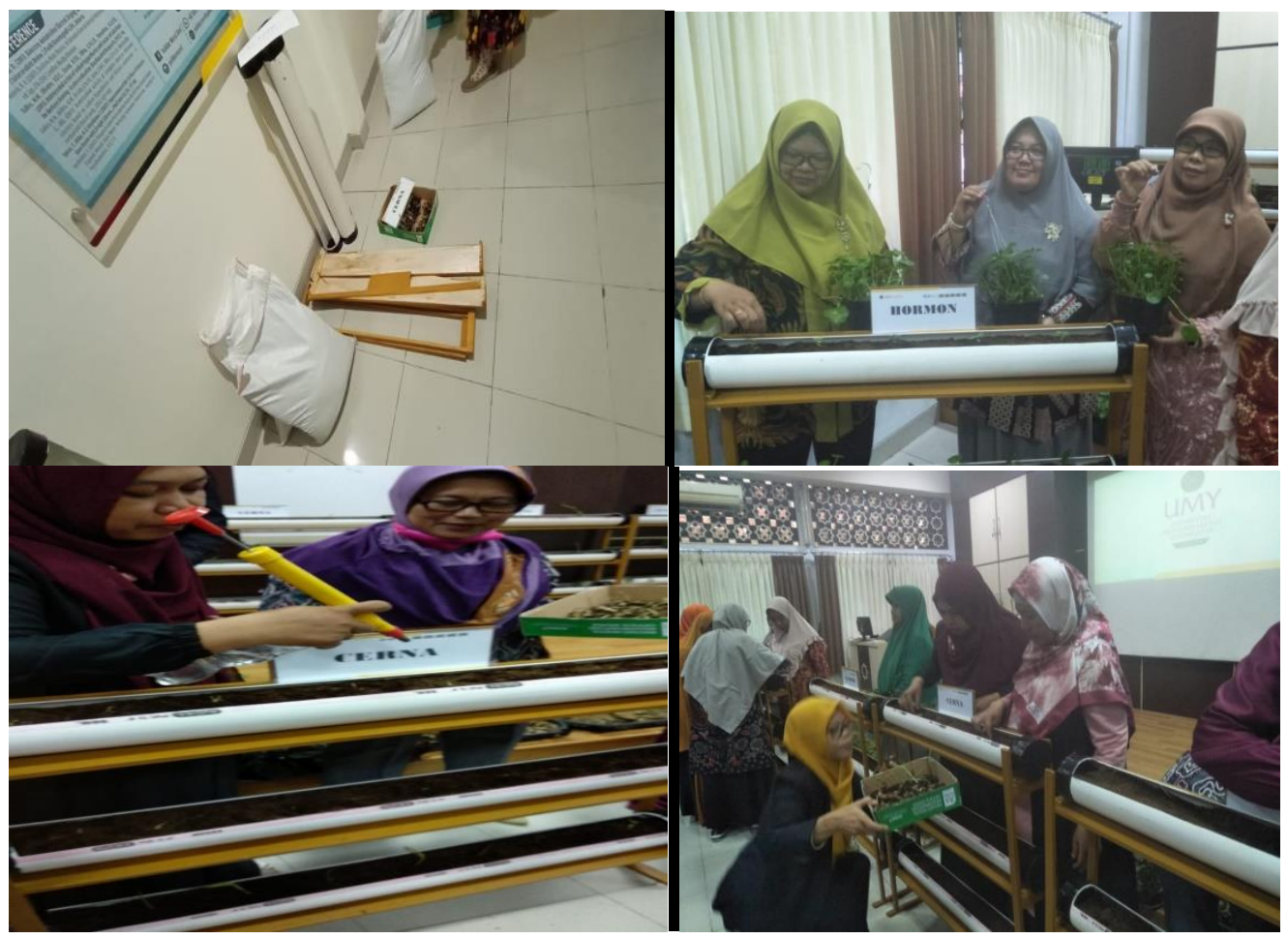

Gambar 4. Paket dan proses acara 
Topik Tanaman Obat Keluarga (TOGA) yang diangkat pada pengabdian ini berupa paket pengobatan beragam penyakit yang marak dikalangan masyarakat, diantaranya gangguan pada nafas, hormon, pencernaan, jantung dan syaraf. Tanaman obat keluarga disesuaikan dengan banyaknya ganguan kesehatan yang dialami di tiap Daerah. Pimpinan Wilayah Aisyiyah Sleman menggembangkan TOGA kunyit, jahe, kencur. Pimpinan Wilayah Aisyiyah Bantul mengembangkan TOGA mint, serai, sirih. Pimpinan Wilayah Aisyiyah Kulonprogo mengembangkan TOGA pegagan, daun ungu, jahe. Pimpinan Wilayah Aisyiyah Kota Yogyakarta mengembangkan TOGA kunyit, sirih merah, temu lawak. Pimpinan Wilayah Aisyiyah Gunung Kidul mengembangkan TOGA pegagan, stevia dan kemangi. Berikut gambar paket yang digunakan dalam acara dan proses acara yang telah dilaksanakan:

Pada kegiatan pengabdian sebelum dilakukan kegiatan, para peserta dilakukan pretes dan postes sebanyak 30 soal pilihan ganda yang diikuti oleh 26 peserta, setelah dilakukan pretes peserta diberikan materi, sosialisasi modul, dan workshop penanaman. Kemudian dilakukan postes. Dari Hasil Pelatihan yang kami lakukan terjadi peningkatan pemahaman sebesar 13,7 \% dari rerata nilai nilai 55,9 meningkat menjadi 69,62. Hal ini sejalan dengan penelitian sari yang meningkat hanya sebesar $13 \%$. Poin pertanyaan yang masih kurang menjawab $50 \%$ benar adalah poin no 6 (antihistamin pada pada sirih), 14 (khasiat daun ungu), 23 (nama latin temulawak), 24 (manfaat kencur), 26 (manfaat menthol), 28 (nama latin kemangi) dan 29 (fungsi sirih merah). Peningkatan cukup baik karena untuk meningkatkan pemhaman tidak bisa hanya dilakukan dalam satu hari perlu beberapa pengulangan agar menjadi lebih dipahami. Kegiatan ini mendapat apresiasi yang sangat baik oleh pihak mitra dan peserta, mereka puas dengan kegiatan ini dan sangat bermanfaat apalagi dengan masa pandemi ini. Sesuai dengan penelitian Nugraha (2015) pelatihan dapat memberikan manfaat untuk memberikan pengetahuan tingkat aman konsumsi herbal. Kegiatan pengabdian ini selain bisa digunakan untuk aktifitas di rumah juga bisa memanfaatkan lahan sempit serta tanaman tersebut dapat membantu dalam meningkatkan sistem imun sehingga bisa digunakan alternative untuk mencegah penyebaran rantai covid 19. Sejalan dengan penelitian Swardana (2020) yang menyebutkan kegiatan optimalisasi pekarangan yang ditanami sayuran dan TOGA dapat membantu krisis pangan dan penelitian Wibowo dkk (2020) yang menyebutkan TOGA banyak manfaatnya sebagai anti oksidan dapat meningkatkan kekebalan tubuh serta mendapatkan kondisi tubuh yang prima sehingga bisa menangkal covid 19. Pihak mitra dan kader berharap pelaksanaan program ini diharapkan bisa berkelenjutan dan pihak pengabdi berharap pembentukan kader dapat dimplementasikan di daerahnya masing-masing.

\section{Simpulan}

1. Hasil survei Kepuasan ke pihak mitra menyatakan puas dengan kegiatan pengabdian ini.

2. Terjadi peningkatan pemahaman sebesar $13,7 \%$ dengan adanya sosialisasi modul SALING TOGA dan pelatihan.

3. Program ini diharapkan bisa berkelanjutan dan pihak pengabdi berharap pembentukan kader dapat dimplementasikan di daerahnya masing-masing.

\section{Ucapan Terima Kasih}

Penulis mengucapkan terima kasih kepada Lembaga Penelitian dan Pengabdian Masyarakat Universitas Muhammadiyah Yogyakarta atas pemberian hibah Pengabdian Kemitraan Masyarakat melalui SK hibah 031/PEN-LP3M/I/2020sehingga kegiatan ini dapat berjalan dengan lancar dan optimal serta bermanfaat untuk mitra kegiatan. Penulis juga mengucapkan terima kasih kepada mitra pengabdian yaitu LLHPB PWA Yogyakarta yang telah mendukung sehingga kegiatan ini dapat berjalan dengan lancar. 


\section{Daftar Pustaka}

Arifah, U., 2017. Pemberdayaan Keluarga sebagai Model Pemberdayaan Masyarakat. Tamkin: Jurnal Pengembangan Masyarakat Islam, 2(1), pp.96-118.

Gendrowati, F. 2014. TOGA: Tanaman Obat Keluarga. Jakarta: Padi. Halaman, 17.

Hikmat, A., Zuhud, E.A.M., Sandara, E., Sari, R.K. 2011. Revitalisasi konservasi tumbuhan obat keluarga (TOGA) guna meningkatkan kesehatan dan ekonomi keluarga mandiri di Desa Contoh Lingkar Luar Kampus IPB Darmaniaga Bogor. Jurnal Ilmu Pertanian Indonesia. 16 (2); 71-80.

Mahdi, nor, Perwitasari, kertia, 2016. Studi Pharmacovigilance Obat Herbal Di Puskesmas Kasihan II Bantul, journal.uad.ac.id/index.php/Media-Farmasi/article/view/5744, diakses 7 Januari 2020

Nugraha, S. P. 2015. Pelatihan Penanaman Tanaman Obat Keluarga (TOGA). Asian Journal of Innovation and Entrepreneurship, 4(01), 58-62.

Sari, S. M., \& Rasyid, T. A. 2019. Pemanfaatan Tanaman Obat Keluarga (Toga) pada Masyarakat. Dinamisia: Jurnal Pengabdian Kepada Masyarakat, 3.

Swardana, A. 2020. Optimalisasi Lahan Pekarangan Sebagai Salah Satu Upaya Pencegahan Krisis Pangan di Masa Pandemi Covid-19. Jagros: Jurnal Agroteknologi dan Sains (Journal of Agrotechnology Science), 4(2), 246-258.

Wibowo, D. E., Madusari, B. D., \& Ardianingsih, A. 2020. Pemberdayaan Keluarga Menghadapi Pademi Covid 19 Dengan Penanaman Dan Pemanfaatan Tanaman Obat Keluarga Di Kelurahan Degayu Kecamatan Pekalongan Utara. Pena Abdimas, 1(1).

Pimpinan Wilayah Aisyiyah, www.yogyakarta aisyiyah.or,id diakses 6 Januari 2020).

Wawancara dengan Ketua LLHPB PWA DIY 